\title{
Resiliens mellem individ og livsform
}

AF MARTIN D. MUNK

SLAGMARK \#73

SIDER: 8I-IO2

I denne artikel prøver jeg at adressere, at resiliens giver mening, hvis det forstås og anvendes inden for rammerne af begreber om fællesskabssamfund, livsformer, levedygtige/bæredygtige husholdninger over generationer og de store samfundsforandringer, som har fundet sted siden begyndelsen af det 20. århundrede. Hvis resiliens isoleres til en psykologisk forståelsesramme, som handler om individers modstandskraft, når de agerer på livets vej, udfordres, eller udsættes for kriser, så reduceres modstandsdygtighed til de enkeltes menneskers evner og karakteristika. I stedet er det oplagt at forstå henholdsvis en styrkelse eller en svækkelse af resiliens, som noget der kan ske i forhold til, hvor godt en livsform eller et fællesskab klarer udfordringer eller kriser, og dermed også i hvilken grad levedygtige husholdninger (familier) mestrer at varetage familiens muligheder for at leve et bæredygtigt liv. Dette betyder og forudsætter i virkeligheden, at livet leves i en livsform, hvor familiens liv leves stabilt og hvis interesser varetages ved at fastholde en vis autonomi og social forankring i et fællesskab, en videreførelse af familien og slægten gennem reproduktive strategiske langtidsholdbare handlinger, øje for vigtigheden af profylakse (det vil sige et sundt liv og med fokus på egen biologi), muligheder for at uddanne og kvalificere sig til en omsættelig indkomst, og ikke mindst evnen til at skabe og have adgang til arbejde i bred forstand.

Imidlertid er disse betingelser truet af en velfordskapitalisme, et samfund konstitueret ude og inde fra af en statsbaseret fordeling af velfærd og af en i stigende grad selvreguleret markedsbaseret kapitalisme, idet et selvreguleret marked i ren form både er urealistisk og uholdbar, som vist af Karl Polanyi, forfatteren til klassikeren The Great Transformation. Det vil sige truslen kommer fra en monopoliseret 
kapitalistisk produktionsmåde, som omslutter de sociale relationer i stedet for det omvendte (Polanyi, 1944/2001), og fra en ikke familie- og slægtsstøttende stat, som samlet har ført til mindre autonomi, svækkelse af den simple vareproduktion og tilhørende husholdninger blandt de selvstændige og lønmodtagere.

Disse betingelser er tillige truet af en modernitet, som har ført visse typer af frisættelse og frigørelse med sig, men som også har ført til svækkelse af levedygtige husholdninger og stabile familier, det vil sige defineret ved fælles produktionsenheder i familien (slægten) med respekt for jorden, omgivelserne, håndværket og kundskaber (se fx Goode, 1963; Lenski, 1966, kapitel 6-7 med fokus på havebrugssamfund). I sådanne små samfund er den økonomiske ulighed lav og den intergenerationelle mobilitet relativt stor (lille påvirkning af forældreindkomst på indkomsten i 2. generation) svarende til niveauer i skandinaviske samfund (jf. Mulder et al., 2009) og i visse amerikanske regioner og byer (jf. Chetty, Hendren, Kline, \& Saez, 2014). Svækkelsen af levedygtige husholdninger bidrager netop ikke til en egentlig bæredygtig udvikling og en styrkelse af resiliens.

Husholdningers overlevelse, økonomi og livsform er historisk set i stigende grad blevet mere og mere afhængige af tilgængelige offentlige arbejdspladser, offentlige tilbud og job i store firmaer, det vil sige på den ene side af en stat, som ikke primært med dens politik satser på at understøtte etablering og fastholdelse af familien (fx i dag med mere institutionalisering af barndommen og understøttelse af enlige forældre etc.), og på den anden side af storkapitalistiske firmaer. Det vil sige, at familiers grundlæggende økonomi er ikke så meget baseret på lokale fællesskabssamfund med tilhørende udveksling af arbejde og tjenester, men mere funderet på socialisering i og uddannelse i en række institutioner, og på at skaffe sig et arbejde i det store samfund med et øget ubæredygtigt energi- og miljøforbrug til følge. (Udvikling af nye teknologier kan dog til vis grad opbløde denne tendens).

Moderniteten, forstået som kulturel og social frisættelse, får en indvirkning på graden af stabilitet i danske familier. Eksempelvis ses dette af en lav ægteskabsgrad blandt børnefamilier, en markant stor skilsmisseprocent gennem de seneste generationer (Christoffersen, 2004; Danmarks Statistik, 2014a, 2015) - undtagen i meget velstående familier (Munk, 2014b) - og af at en stigende andel af børn lever i brudte familier - til tider med svag tilknytning til den ene forælder og dennes familie og den øvrige slægt: 
Udviklingen i skilsmisseantallet efter anden verdenskrig er af nogle forskere blevet beskrevet som en revolution af familiemønsteret, fordi udviklingen af familieseparationer har været særligt markant inden for en forholdsvis kort årrække (Goode, 1963). Antagelserne om baggrunden for denne udvikling var, at de moderne familier i mindre grad udgjorde en fælles produktionsenhed, og at båndene til den øvrige slægt er blevet slækket, således at den ikke kan støtte familien i krisesituationer (Christoffersen, 2004, s. 11).

I William Goodes klassiker World Revolution and Family Patterns (1963) siges industrialiseringen at påvirke familieformerne, og omvendt, som fører til en udvikling hen imod den konjugale familieform, det vil sige en ægteskabelig familietype (som egentlig Émile Durkheim skriver om første gang i 1892, og som publiceres i revue philosophique i 1921) (Goode 1963, s. 8, 12-13). Denne familieform er defineret ved at bestå af mor, far og børn, med en mindre tilknytning til slægten i hverdagen, dog uden at blive til en kernefamilie, som hos Talcott Parsons (jf. Morgan, 1975, s. 52). Goode (1963, s. 70-81 og s. 370-371) afskriver således ikke bedsteforældrene som sådan, da de på en eller anden måde kan være der for børnebørnene. Eksempelvis kan familien bestående af far og mor og børn udvides ved, at en datter får børn, således at faderen bliver morfar, og moderen bliver mormor, som kan indebære, at de får en emotionel og social tilknytning til barnebarnet. Der er imidlertid en social gradient, så vidt angår tilknytningen til slægten, som ifølge Goode (1963, s. 12-13) særligt i de lavere sociale lag står svagere, da deres frihed består i at sælge deres arbejdskraft på arbejdsmarkedet, og integreres derved i højere og hurtigere grad ind i industrien, eller det som udvikler sig til det, jeg kalder for velfærdskapitalismen. Mellemlagene og de øvre sociale lag er på forhånd mere succesfulde i velfærdskapitalismen, simpelthen fordi de ejer virksomheder eller organisationer, og er med til at styre dem. Det er fra disse sociale lag, at rekrutteringen til de højeste sociale positioner primært sker. Det er ligeledes i de øvre sociale lag, at den udvidede familie (herunder bedsteforældre, onkler, tanter) og slægten samt valg af partner (ægteskab) stadigvæk anses for at være afgørende (ikke nødvendigvis ved, at de tre generationer bor under samme tag, i den samme husholdning, langt fra, men ved at have en tæt kontakt med den øvrige familie, jf. Christoffersen, 2004, s. 15-21, og referencer heri), og derfor er under en vis kontrol med en større grad af gensidig hjælp til følge, igen til dels modsat andre sociale lag. Det er i hvert fald antagelsen. 
Den amerikanske populationsforsker Andrew Cherlin (2012) påpeger i en kritik på den ene side, at Goode ikke helt var i stand til at forudse, at den ægteskabelige familie tillige var under opløsning, og ikke blev den endelige og eneste familieform i det moderne samfund, og på den anden side, at Goode fik ret i, at forældres kontrol med deres børn aftog. Cherlin synes imidlertid ikke at have blik for, at disse tendenser er ulige fordelt henover de sociale lag, idet familiebåndet og ægteskabet i vid udstrækning stadig fastholdes i blandt familier i de øvre sociale lag via transmissioner (overførsler) mellem generationerne, også i lande som Sverige og Danmark (Björklund, Roine, \& Waldenström, 2012; Munk, Bonke, \& Hussain, 2016; Bonke, Hussain, \& Munk, 2015). Cherlin (2012) har tilmed ikke øje for, at Goode faktisk havde historiske ægteskabsstatistikker (målt på skilsmisseraten mellem 1900-1960) inkluderet sine analyser (jf. Goode, 1963, s. 82), hvor variationen henover landene viser, at den intakte ægteskabelige familie ikke nødvendigvis står mejslet i granit, slet ikke i lande som USA (efter 1930), Danmark (efter 1945) og Sverige (efter 1956), hvor skilsmisseandelen vokser. Omkring afslutningen af Anden Verdenskrig opleves en stigende skilsmisserate i nogle lande.

I takt med ændringen af familiemønstret i samfundet er især de lavere sociale lag med velfærdsstatens mellemkomst i stedet blevet mere afhængig af overførsler fra staten, som i perioder har ført til mindre social mobilitet. Afhængigheden af staten i den forstand har imidlertid med tiden også vundet indpas i store dele af mellemlaget.

Disse træk af samfundsudviklingen har samlet set ført til en svækkelse af grundlaget for en samfundsforankret og husholdningsbaseret resiliens.

Dermed er mit mål med artiklen at bidrage med en analyse af forholdet mellem levedygtige husholdninger og samfundsforandringer for derigennem at tilbyde en mere optimal opfattelse af begrebet om resiliens. Tillige definerer jeg begrebet i et sæt af ikke-kognitive egenskaber, som en måde at forstå den menneskelige psyke som værende afhængig af en social kontekst.

\section{RESILIENS SOM IKKE-KOGNITIV EGENSKAB, LIVSFORMER OG OIKOS}

Resiliens, typisk forstået som modstandskraft, modstandsdygtighed, robusthed eller sommetider livskraft, indgår som begreb i en række forskningstraditioner, især inden for miljøvidenskaben - som har særligt fokus på bæredygtighed - og psyko- 
logiske og økonomiske undersøgelser af ikke-kognitive egenskaber (fx Almlund, Duckworth, Heckman, \& Kautz, 2011), eksempelvis vedholdenhed (persistens) eller impulskontrol. I sociologien er studier af disse typer af karakteristika tillige undersøgt (fx Farkas, 2003), og viser sig at være en af de mekanismer, der forhøjer chancen for at fuldføre forskellige typer af ungdomsuddannelser taget højde for familiebaggrund og demografiske karakteristika (jf. Munk, 2013).

Olsson, Jerneck, Thoren, Persson, og O’Byrne (2015), med rødder i økologisk videnskab og filosofi, har imidlertid påpeget en række problemer forbundet med at føre begrebet resiliens ind i samfundsvidenskaberne uden at operere med begreber som magt, struktur og sociale betingelser, idet begrebet har sine rødder i en slags funktionalistisk systemteori (jf. den senere Parsons) og rational choice-teori (jf. Elinor Ostrom) med i flere henseender indbyggede problemer. Det demonstreres af forfatterne, at resiliens er vildledende med hensyn til forklaringen og forståelsen af en række problemer. Det kunne for eksempel være med hensyn til afgørende skillelinjer, når det gælder succes i uddannelsessystemet eller mental-kropslig stress på universiteterne, som begge i stigende grad gøres til individuelle problemstillinger ved at tænke i individuel robusthed, som løsningen på problemerne. Hvis man på den anden side accepterer at resiliens og tilsvarende kategorier, som fx vedholdenhed, har en vis forklaringskraft, kan begrebet anvendes, men ikke uden at forstå det som betinget af forhold som strukturer, langsigtede reproduktionsstrategier (Munk, 2014a) og livsformer (jf. Højrup, 1995; Høst, 2015). I sidstnævnte tradition begrebsliggøres fem hovedlivsformer, nemlig den selvstændige livsform, lønarbejderlivsformen, den karrierebundne livsform og kapitalist/investorlivsformen samt embedsmandslivsformen. Den selvstændige livsform defineres ud fra den enkle vareproduktion, medens de andre livsformer henter sine eksistensbetingelser fra den kapitalistiske produktionsmåde. Dertil kommer to centrale undervarianter, som henviser til kvinders livsformer som husmoder, der henter sine eksistensbetingelser i lønarbejderlivsformen, og baglandslivsformen, der har sit udspring i karrierelivsformen (jf. Rahbek Christensen, 1987; Højrup, 1995: for et kritisk interview med Højrup, se Jespersen \& Sandberg, 2006). I Munk (1990) viste jeg hvorledes, der i den strukturelle livsformsteori savnes et intensionalt begreb (det vil sige et begreb, som henter sin mening og logik gennem relationer til andre begreber) om husholdningers og generationers habitusser (som på visse stræk svarer til livsformer), som udvikles under eksistensbetingelser, der er forskellige fra de eksistensmuligheder, 
som de møder og er oppe imod, et fænomen som i livsformsteorien kaldes for neokulturation. Det vil sige habitus produceres og fungerer under forskellige modes of generation, det vil sige eksistensbetingelser, som implicerer det mulige og det umulige (Bourdieu, 1977, s. 78) eller som i en tidligere 1972 version af Outline of Theory of Practice beskrives som generationsbestemte produktionsmåder (Bourdieu, 2005, s. 201). Derved understreges betydningen af generationsvilkår og af at familiers habitusbaserede strategier udspringer og iværksættes under forskellige betingelser, hvilket indebærer at langsigtede strategier socialt set er ulige og derved bliver afgørende for, at nogle familier klarer sig anderledes fordelagtigt end andre familier (se nedenfor).

I artiklen her anvender jeg begrebet livsform empirisk sensitivt for at fremhæve problemet med, at især livsformen som selvstændig er væsentligt reduceret i udbredelse, og at navnlig de fire andre hovedlivsformer samt andre former eller varianter (sociale overførselstyper) dominerer i det nutidige samfund, idet lønmodtagerlivsformen kan være i privat eller offentlig regi. Tillige henfører jeg begrebet til det aristoteliske hushold (oikos), som er økonomisk selvbærende, og som med stor enighed blandt klassikere betragtes som den oprindelige fundamentale enhed bestående af husholdning(er), familier over flere generationer, økonomi og typisk jord (Foxhall, 1989; Davies 1992, s. 290; Højrup, 2002, s. 66, efter Aristoteles: Politikken, 1252b; se også Lacey, 1968 og Cox, 1998). Oikos henviser således til ejendom, familie og en samlet produktionsenhed, medens formen oikia henviser til hushold og den fysiske bygning (jf. MacDowell, 1989, s. 11-15; Cox, 1998, s. 132 og s. 135). Her anvendes betegnelsen oikos, hvori generationsaspektet i familien ofte fremtolkes: "Idet begrebet oikos omhandler personer, refererer det normalt til slægtslinjen mellem far og søn gennem successive generationer" (jf. MacDowell, 1989, s. 15; se også Cox, 1998, s. 141-143, som til tider regner naboskabet med til oikos).

De mange selvbærende husholdninger (oikoi) giver samlet ophav til polis, bystaten (Højrup, 2002, s. 65, 2006), idet Cox (1998, s. 132) påpeger, at polis samlet set er forudsætningen for disse oikoi, juridisk, statsligt etc. Polis er således emergent, hvilket vil sige, at helheden defineret ud fra at bystaten er noget andet og mere end blot summen af de enkelte dele. Boltanski, og Thévenot (2006, s. 73) fremhæver i deres værk On Justification, via Aristoteles' Politikken (1253a), at værdien af hjemlige fællesskaber defineres ud fra staten som institution (polity), og ikke omvendt. På den anden side skriver Aristoteles i Politikken (1252b), at fællesskaber, og der- 
med økonomi, opstår ud fra flere husholdninger. Indførelsen af begrebet oikos om husholdning, økonomi og familie i forening, tilbyder således en grundlæggende forståelse af, hvorfra økonomien også vokser. Det er en problematik, som Polanyi (1944/2001, s. 55-56) diskuterer ved at kaste lys på princippet om husholdning (jf. Aristoteles), der imidlertid ikke går forud for principper om gensidighed og omfordeling. Her er fokus på, at der ikke alene produceres og skabes værdier til producenten og familiens eget brug (modsat profit) i husholdet, men til et bredere socialt fællesskab, idet overskuddet af værdier kan veksles på et marked (en tilsvarende distinktion mellem husholdning og profitskabelse findes allerede hos Max Weber i hovedværket Economy and Society i del I, kapitel 2(10) og i del II, kapitel 4 om husholdning, virksomhed og oikos, første gang offentliggjort i 1922). Todelingen af en husholdning med produktion til brug, og en anden pengedrevet produktion til marked, fastholdes af Polanyi, med vægt på at førstnævnte har forrang. (Senere forskere har fokuseret på hvorledes de fælles naturbaserede goder på en bæredygtig måde kan udgøre grundlaget for de selvbærende husholdninger og den selvstændige livsform, uden at disse goder overlades til investorlivsformen, som den førte politik ofte indebærer, se fx Andreasen \& Højrup, 2008).

Da det kapitalistiske marked og staten i stigende grad overtager styringen af familierne i det moderne samfund, så forsvinder eller ændres betydningen af husholdningen som den mest afgørende enhed i lokalsamfundet (nogle gange betegnet civilsamfundet), hvori familien lever og hvorfra økonomien udspringer. Denne forandring af samfundet fører til tab af sociale bånd, da den "fædrene arv" i en familie eller en slægt ikke alene inkluderer jord og produktion, men også relationer til kunder og klienter, i det hele taget hele deres sociale netværk af relationer og alliancer, som over tid og generationer skal fastholdes og vedligeholdes for at bevare det afgørende bånd og ære. Derfor tager det oftest generationer at erhverve og fastholde holdbar symbolsk kapital (Bourdieu, 1977, s. 178), som skabes på baggrund af kontinuerlige udvekslinger, egenskaber og handlinger, det vil sige former for kapital, som i specifikke grupper giver anerkendelse i form af eksempelvis adgang til familie, ressourcer, prestige, goodwill, eller loyalitet overfor firmaer eller varemærker. Det betyder, at andre former for kapital kan have en symbolsk større eller mindre udvekslingsværdi.

Ifølge Olsson et al. (2015) er der på den ene side således betydelige faglige problemer med resiliensbegrebet i samfundsvidenskaben. På den anden side ser begrebet 
ud til at have en vis betydning. Især, hvis det tolkes inden for en bred palet af kategorier, som indfanger ikke-kognitive egenskaber. Det kan tilmed vinde i styrke ved mere radikalt - udover begrebet om bæredygtighed - at indføre et begreb om levedygtighed eller mere specifikt levedygtige livsformer/husholdninger (oikos). Det vil sige livsformer og husholdninger, som kan udgøre grundlaget for fællesskabssamfund (se nedenfor i afsnittet om fællesskaber), hvor levedygtige livsformer og individer er hinandens forudsætninger i stedet for at tænke i et løsrevet individualiseret resiliens begreb.

\section{VELFERDSKAPITALISMEN OG SOCIAL STRATIFICERING}

Min tese er, at velfærdskapitalismen, den dominerende samfundsform gennem generationer, og individualiserede forsøg på løsninger af sociale problemer, har ført til en manglende erkendelse af, at fællesskabssamfund forudsætter betingelser for etablering og fastholdelse af levedygtige livsformer (herunder overholdelse af princippet om oikos), stabile generationsoverførsler og optimale chancer for arbejde og familiedannelse i befolkningen.

Velfærdskapitalismen har beviseligt givet muligheder. Talrige studier (Bonke \& Munk, 2002; Esping-Andersen, 1990, 1999; Pedersen, 2011, 2014 m.fl.) har argumenteret for velfærdsstatens tilbydende karakter med historisk set bedre levevilkår, friheden til arbejde, en begrænset social ulighed, mulighed for (gratis) uddannelse, gode jobmuligheder (især som funktionær), betydelige offentlige investeringer i uddannelse og andre institutioner, og for en relativ stor kompensationsgrad i forbindelse med arbejdsløshed og andre sociale begivenheder.

Ikke desto mindre er der en slånde tendens til, at denne samfundsform stadig medvirker til sociale problemer i form af øget social stratificering og sociale opdelinger med hensyn til velstand, jobmuligheder, uddannelsessucces, symbolsk kapital og familiedannelse (jf. Bourdieu, 2014; Munk, 2014b). Således er det blot dele af befolkningen, som i overvejende grad lever i stabile familier (Dahl 2014) med velrenommerede positioner på arbejdsmarkedet, om end arbejdspresset med stigende præstationskrav er stort, medens andre dele af befolkningen kæmper med at hænge på med stigende uddannelseskrav og krav om nyttige færdigheder og effektivitet (Pedersen, 2011) og usikkerhed. Endelig står dele af befolkningen på kanten af eller uden for arbejdsmarkedet oftest i kombination med liv i brudte familier 
(Christoffersen, 2004). Tilmed viser en historisk trend over de seneste ca. 30 år, at indkomstmobiliteten mellem generationerne er mindsket over tid, det vil sige børns indkomst som voksne bliver i stigende grad mere og mere afhængig af forældrenes indkomstniveau (jf. Harding \& Munk, 2016). (Var børns indkomst som voksne derimod blevet mindre afhængig af forældrenes indkomst ville den intergenerationelle (sociale) indkomstmobilitet være forøget). Denne trend er i overensstemmelse med udviklingen internationalt, hvor den økonomiske ulighed i mange lande ligeledes er vokset eksplosivt. Thomas Piketty (2014) viser i sin store bog om kapital: Capital in the Twenty-First Century grundlæggende at $\mathrm{r}>\mathrm{g}$, det vil sige genvinsten ved kapitalinvesteringer ( $r$ ) i en markedsøkonomi giver langt mere pote end indtjening af arbejdsløn (g), så det konstateres at de rige i nogle lande ejer meget mere af den samlede indkomst, modsat tidligere perioder, hvor $\mathrm{r}<\mathrm{g}$, det vil sige hvor kapitalinvesteringerne (r) giver mindre end indtjening af løn (g) (se Meikle, 1996 for to betydninger af velstand). Dette bekræftes også i Munk et al. (2016) som samstemmende med svenske resultater (jf. Björklund et al., 2012), peger på, at kapitalindkomst i familierne udgør en væsentlig transmissionskilde til den relativt lille intergenerationelle mobilitet i toppen af samfundet. Med andre ord, den sociale stratificering består og øges.

Sociale problemer som fødes under velfærdskapitalismen er i de senere år forsøgt løst og adresseret via begreber om resiliens, forstået som modstandsdygtighed givetvis i takt med udviklingen af New Public Management og konkurrencestaten (jf. Pedersen, 2011) og ikke mindst statens mediering af og ret til at afgøre hvem og hvilke institutioner der tildeles symbolske og økonomiske ressourcer eller det modsatte (Bourdieu, 2014). Forskellige typer af problemer har således ført til et skærpet fokus på, at familier, arbejdsløse, børn og unge, elever, syge, studerende, forskere m.fl. i stigende grad skal udrustes til at blive modstandsdygtige i forhold til øgede krav om bedre performance, større resultater, øget job parathed, tilgængelighed, omstillingsparathed etc.

\section{LEVEDYGTIGE HUSHOLDNINGER I FÆLLLESSKABER}

Det grundlæggende problem er imidlertid ikke primært, at individer ikke er modstandsdygtige, men at generationsreproduktionen, dvs. social og familiemæssig reproduktion og socialisering, og fastholdelse af levedygtige livsformer/husholdnin- 
ger, er blevet udgrænset som et grundlæggende princip. I visse tilfælde er det dog indlysende, at generationsreproduktionen kan være negativ, tidligere i forhold til børnedødelighed og dårlige levevilkår, senere i forhold til manglende familiestabilitet, risikofyldte familieformer, begrænsede sociale netværk, frafald i uddannelserne og det ikke at arbejde.

I stedet for at løse sociale problemer via et isoleret begreb om resiliens inden for rammerne af det store rationelle samfund (svarer til begrebet Gesellschaft hos Ferdinand Tönnies (1957)) er etableringen og fastholdelsen af livsformer, familie og husholdninger - konstituerende for fællesskaber/lokalsamfund (Gemeinschaft, jf. Tönnies) - en holdbar løsning, hvorfra modstandskraft kan udspringe.

De livsformer, handlinger og adfærd som iværksættes i familierne og husholdningerne er afgørende for hvordan fremtidige børn, børnebørn og oldebørn vil klare sig - eller ikke vil klare sig. En overset reproduktionsparameter i megen sociologisk/samfundsvidenskabelig teori og forskning er netop det levedygtige oikos, det vil sige det livgivende hushold, den kapable og robuste familie, med understøttende værdier, der er i stand til at tage vare på sig selv og de kommende generationer, såvel socialt, arbejdsmæssigt, mentalt som økologisk. Den erkendelse mangler i betydelige dele af resiliensforskningen og også i velfærdsstatsforskningen. Det afgørende for at opnå et holdbart, modstandsdygtigt og godt liv i hele befolkningen - trods kriser og modstand - er muligheden for at stifte familie, skaffe sig en god bolig i et levende og bæredygtigt lokalsamfund med tilhørende virksomheder, skoler, fæller/ kammerater og et arbejde.

Mange teorier har med ret fokuseret på samfundstype, magt, markedsvilkår og civilsamfund, som Olsson et al. (2015) også er inde på, og selvom der findes sociologisk teori som har familien (se fx Dahl, 2014) eller husholdningen som centrum for begrebsdannelse og undersøgelser, så har teorierne og anvendelserne heraf manglet $\mathrm{i}$ alt for mange år. Det skyldes dels at samfundet erhvervs- og arbejdsmarkedsmæssigt strukturelt ændres, dels et manglende fokus på familien og husholdningen, et fokus som i stedet rettes på velfordsregimer, det vil sige grundlæggende måder hvorpå velfærdssystemer indrettes i forskellige lande; regimer refererer således i Esping-Andersen (1999) til hvilken måde velfærdsproduktionen er allokeret mellem stat, marked og familier, hvilket indebærer et socialdemokratisk regime, et liberalt regime og et konservativt regime. 


\section{URBANISERING, ERHVERV OG STRUKTUREL MOBILITET}

Siden 1960'erne har der været en stigende tendens til urbanisering og udflytning fra provinsen til byerne, en udjævning af de sociale forskelle mellem kønnene, da kvinderne blev bedre uddannet (Munk, 2008) og i langt højere grad kom ud på arbejdsmarkedet. Ikke mindst har udviklingen medført en historisk set lav andel af selvstændigt erhvervsdrivende, med et markant fald siden 1920 og videre efter Anden Verdenskrig, en historisk stigning i andelen af funktionærer, samt formel svækkelse af den økonomiske ulighed (set over 140 år, med en stigning siden 1992, jf. Atkinson \& Søgaard, 2013; se også Bonke \& Munk, 2002). Ikke mindst er en social opdeling i, hvem der har arbejde, og i hvem der ikke har arbejde, meget tydelig i dag. Dette medfører manglende lige chancer for at have et arbejde for alle livsformer, hvilket i sig selv kan bidrage til forskellige grader af resiliens. Mulighederne for at reproducere sig selv og etablere familie er for en dels vedkommende blevet forringet over tid - især for en stor gruppe af medborgere, som står uden for eller på kanten af arbejdsmarkedet, men også for andre grupper. Mere grundlæggende har velfærdskapitalismen medført en forandring af samfundet, hvad forandringen af erhvervsstrukturen tydeligt peger i retning af.

Den strukturelle mobilitet, forstået som social mobilitet, steg voldsomt $\mathrm{i}$ årene efter 1945 og frem til omkring 1980'erne, især på grund af en grundlæggende forandring af erhvervsstrukturen i Danmark. De tre store livsformer, dvs. lønmodtager jobs i velfærdsinstitutionerne, jobs i store private virksomheder samt offentlig forsørgelse, har således vundet indpas over nogle generationer. Den fjerde livsform bestående af små og mellemstore virksomheder er samtidigt svundet ind til at ligge på omkring en andel på 7-8 \% i dag, hvor den i 1920 lå på ca. 28 \% (jf. egen opgørelse via Danmarks Statistiks kilder over befolkningen). Denne virksomheds- og livsform udgør i dag stadigvæk hovedparten af danske firmaer, som historisk set i høj grad har ført til - og stadigvæk skaber - jobmuligheder for de mange, også for de lidt skæve eksistenser, idet vi ved, at $65 \%$ af den private jobskabelse sker via småog mellemstore virksomheder, medens resten sker i store virksomheder (Danmarks Statistik, 2014b).

Der er en risiko ved at være selvstændig erhvervsdrivende, hvilket illustreres af at de findes både blandt de rigeste og fattigste grupper i samfundet. Livsformen som selvstændig og entreprenør ses således ikke som en særligt attraktiv livsbane. 
Kriser, risici og fortløbende generationsoverførsler i familiefirmaer kan imidlertid fungere som springbræt til skabelsen af nye langsigtede ideer, varige værdier og udbygning af virksomheden ved at udvikle en orientering og mentalitet for en praksis som entreprenør med udspring i de familiebaserede kapabiliteter (det vil sige mulige funktionsmåder) og ressourcer (Zellweger, Nason, \& Nordqvist, 2012, s. 137) samt strategier.

Empiriske undersøgelser viser, at overlevelsen af firmaer er god i lokalsamfundet, specielt for de som kender til området, trods det at jobskabelsen i firmaer i storbyen er noget bedre (Dahl \& Sorensen, 2012). Der er således grobund for at skabe firmaer og nye jobs i provinserne, selvom mange skulle tro det modsatte. Her står muligheden for generøse sociale overførsler i nogen grad i vejen for at skabe flere firmaer og jobs (Sorensen \& Sharkey, 2014).

\section{AFHENGIGHED, LANGSIGTEDE STRATEGIER OG GENERATIONSKONTRAKT}

Dermed er medborgere i stigende grad blevet afhængige af andre, enten andres virksomheder (som i disse år i stigende grad ser efter mere favorable produktionsbetingelser), offentlige institutioner eller systemer i staten. Paradokset er således, at velfærdsstaten med sine systemer kan generere negative afhængigheder (Beyeler, Christoffersen, Eichenberger, Nannestad, \& Paldam, 2013), som bidrager til, at familier i generationer er dybt afhængige af systemer (herunder sociale overførselsindkomster), som kan komme til at virke kontraproduktivt.

På den ene side kan systemerne komme til at svække familiernes muligheder for at vedligeholde deres evne til at skabe sig selv, og ikke mindst til at tænke langsigtet og tilpasse sig. Især sociale grupper uden for de privilegeredes rækker har historisk set ikke praktiseret eller haft mulighed eller tradition for at tænke og handle langsigtet over mange generationer inden for én husholdning, når det gælder fokus på og skabelse af familie ( $\mathrm{fx}$ mange bor alene, eller i splittede familier, eller har biologisk set ikke længere mulighed for at få børn), egen forsørgelse og mulighed for at fastholde en stabil tilknytning til arbejdsmarkedet.

På den anden side gik udviklingen af velfærdskapitalismen med hensyn til visse forhold formentlig hen og blev en fordel for visse familier (forholdsvis gode offentlige institutioner, en vis infrastruktur etc.), medens andre forhold blev en ulempe (høje skatter, vanskeligt at skaffe billig arbejdskraft og visse typer af regulering etc.). 
Empiriske undersøgelser viser, at navnlig mellemlaget og dele af arbejderlaget efterhånden har praktiseret - især via uddannelsessystemet - at udvide mulighederne for social mobilitet og for bedre livschancer end forældrene og bedsteforældrene - større eller mindre omkostningsfyldt for de socialt mobile (Friedman, 2014) og de berørte institutioner - således at det i dag ikke alene er overlægens datter eller advokatens søn, som har mulighed for at påbegynde en gymnasieuddannelse og for at gå videre i det højere uddannelsessystem, om end det stadig er sådan at børn af akademikere har større chancer i uddannelsessystemet (Munk, 2014a, 2015). Mellemlaget og de aspirerende mellemlag er primært historisk set gået efter de positive sammenhænge mellem uddannelse og sociale institutioner, leveret via offentlige systemer og opkomsten og skabelsen af jobs på arbejdsmarkedet.

Børn og unge fra arbejderlaget har derimod ikke i samme grad haft de samme muligheder i uddannelsessystemet, hvor adgangen til og gennemførelsen af længevarende uddannelse historisk set ikke har været så fordelagtige som for mellemlagets børn og unge, om end der over en 20-årig periode fra begyndelsen af 1980'erne op til begyndelsen af 00'erne fandt en vis social opblødning sted, således at uddannelsesmobiliteten steg. Det tyder hermed på, at børn og unge i familier og generationer i lavere sociale lag ikke så let bliver uafhængig af deres sociale baggrund, eller er i stand til at kopiere adfærden som den udføres i andre sociale lags familier, slægt og fællesskaber. Trods det peger en række studier på, at den udvidede familie i lavere sociale lag i form af bedsteforældre, onkler og tanter kan påvirke graden af uddannelsessucces (Munk, 2014a, 2015; en pointe Goode (1963, s. 12) skitserer som et muligt scenarie, da et slægtsnetværk gennem sociale kanaler positivt kan påvirke mobiliteten).

Omvendt ser det ud til, at mere velstående, ressourcestærke og entreprenante familier gennemgående anvender langsigtede sociale reproduktionsstrategier over mange generationer og således har formået at reproducere sociale positioner i samfundet. Reproduktionsstrategierne angår blandt andet fertilitet, arv, profylakse, uddannelse, ægteskab, økonomi, netværk og relationer, legitimering, udenlandsophold og bosted (jf. Munk, 2014a, s. 189). Undersøgelser af familier viser, at reproduktionen blandt de mere velstillede familier sker gennem mange generationer (Mare, 2011, 2014). På det seneste har Clark (2014) vist, at den sociale mobilitet i virkeligheden er ret begrænset, når reproduktionen og den sociale mobilitet undersøges over rigtigt mange generationer. (Tidligere studier lider af det problem, 
at bevægelserne primært studeres henover to generationer (forældre-børn)). Selv $i$ et land som Sverige viser det sig, at det er de samme familier, som over mange generationer fastholder favorable muligheder i samfundet, formentlig understøttet af en stærk kontrakt mellem generationerne, hvilket står i kontrast til Danmark (jf. Albertini \& Kohli, 2013).

I stedet for fokus på kontrakten mellem generationer har der politisk og socialt i årtier været fokus på, hvordan man via omfordeling kunne ligestille befolkningsgrupper. Man antog, at de rige og andre privilegerede grupper havde skaffet midler og ressourcer på baggrund af ulige vilkår. En del forskning støtter den antagelse, men problemet er, at man ikke har stillet spørgsmålet om de stærke grupper og familier i virkeligheden måske var klogere end de andre. Ikke (kun) i ren intelligensmæssig forstand, men i bredere forstand ved at drage omsorg for, og stille store krav til de næste generationer.

Spørgsmålet om hvordan det kan være, at visse sociale grupper og familier klarer sig bedre end andre og er i stand til - over generationer - at fastholde positioner, blev ikke stillet. Nogle forskere har beskrevet, hvorledes muligheder og robusthed fastholdes og udvides gennem forskellige investeringer i kapitalformer, oftest igennem ihærdige og gennemtænkte reproduktionsstrategier, som indebærer grundige og snedige konverteringer, det vil sige vekslinger af ressourcer og kapital gennem institutioner som uddannelse i indland (Bourdieu, 1996) og i udland (Munk, Foged, \& Mulvad, 2011), ægteskab (Munk, 2014b; Bonke et al., 2015) og formuetransmissioner over generationer (Boserup, Kopczuk, \& Kreiner, 2014) og så vidt hvad angår indkomst (jf. Munk et al., 2016). Forhold, som alle kan bidrage til modstandsdygtighed.

Imidlertid, en afgørende grund til at børn og unge fra arbejderlaget - og til dels mellemlaget - således ikke i samme grad som velstående sociale lag drager fordel af familien er netop, at praksis omkring udnyttelse af slægten og de langsigtede strategier hovedsageligt anvendes og er mulige i de ressourcestærke familier. Kan der dermed ikke finde læring sted? Jo, som førnævnt kan den udvidede familie og slægten spille positivt ind, også blandt børn og unge fra lavere sociale lag. Mere generelt peger det på, at fællesskaber kan bidrage til en øget resiliens. 


\section{FRIGØRELSE, LOKALSAMFUND OG BEGREBSLOGIK}

Mange har set de store samfundsmæssige forandringer som tydelige tegn på frigørelse og i hvert fald frisættelse fra snærende bindinger og traditioner, og muligheder for social mobilitet. Men i stedet for at fokusere så meget på at løsrive sig fra familierne og fra at være rodfæstet i lokalsamfundet, så kan disse i stedet ses som muligheder for at skabe sig gode liv og muligheder ved faktisk at bruge de sociale netværk og lokale virksomheder.

Dette viser sig også ved, at der med hensyn til uddannelsessucces, jobskabelse og chanceulighed og arbejdsgrad er en betydelig grad af geografisk variation (egne beregninger baseret på data fra Danmarks Statistik; se også Sabiers, 2014). Dele af især Vestjylland og dele af Nordsjælland (nordøst for København) ser ud til at klare sig bedre end i resten af landet, fx målt på andelen af ufaglærtes børn som opnår en ungdomsuddannelse eller en videregående uddannelse, eller som er i arbejde. Den geografiske variation kan tilskrives flere forhold (jf. ovenfor).

En hypotese er, at forskellige sociale normer og intensiteten i den protestantiske etik - i sammenhæng med verdslige betingelser - forklarer en del af uddannelsessuccesen (jf. Weber, 1995). Den tyske sociolog Max Weber påpeger i sit klassiske værk: Den protestantiske etik og kapitalismens ånd fra 1905, at der er en nær sammenhæng mellem den protestantiske tro, formidlet i familierne, og arbejdsetikken, det vil sige den indstilling til arbejde og økonomi, som driver kapitalismen frem. En række tyske studier (Becker \& Woessmann, 2009; Schaltegger \& Torgler, 2010) bekræfter, at udviklingen af human kapital og tendensen til at uddanne sig, også blandt unge fra ufaglærte hjem, slår igennem, da mødre blandt protestanter får lov til at lære at læse, og bliver uddannet. Studier af sociologen Gerhard Lenski tyder endvidere på, at den protestantiske orientering giver intellektuel autonomi, som fører til nye opfindelser, hvilket positivt påvirker velstanden. De øgede individuelle livschancer, som den kulturelle udvikling afstedkommer, giver dog også en sideeffekt, der betyder, at husholdningens autoritet disintegreres, da individer bliver mindre tilfreds med at være bundet af ufleksible og rigide livsformer (jf. Weber, 1978, s. 375).

Givet at den protestantiske etik i form af en bestemt begrebslogik (eller det som Durkheim eller Weber ville kalde for sociale normer) eller sociale bånd (forpligtelse) er stærkere til stede, kan tendensen til at uddanne sig slå ekstra hårdt igen- 
nem i nogle geografiske områder, typisk medieret af kammerater og naboer. Noget tilsvarende finder Chetty et al. (2014), ved at indkomstmobiliteten mellem generationerne er større i regioner, hvor bl.a. beholdningen af social kapital (netværk og tillid), graden af lokal familiestabilitet og tilknytningen til kirkeforeninger er stærkere. Forhold som disse bidrager sandsynligvis til en større grad af vedholdenhed, ihærdighed og resiliens, som under visse sociale betingelser er afgørende igennem hele livet (Heckman, 2008; Munk, 2013).

Omvendt kan en svækkelse af den protestantiske etik (ændrede begrebslogikker), det at en betydelig del af den familiemæssige (primære) socialisation er blevet afløst af en offentlig (sekundær) socialisation og tab af sociale netværk gennem kirke og foreninger, samlet set føre til at familiereproduktionen på mange fronter undermineres.

Disse forhold hænger sammen med givende relationer mellem uddannelse og arbejdsmarkeder, hvor man netop i Vestjylland (se også Damgaard, 2002) og andre steder, og sammenhænge, for eksempel er særligt villige til at stille praktikpladser til rådighed (Sabiers, 2014), så unge kan gennemføre en erhvervsuddannelse. Det hænger givetvis sammen med, at man socialt og kulturelt er forpligtet på at hjælpe hinanden gennem stærke fællesskaber og netværk, da forældrene til de unge i højere grad er selvstændige, er faglærte og lever i kernefamilier (Munk, Bohn, \& Baklanov, 2015).

De omtalte protestantiske logikker udfordres givetvis af moderniteten og opkomsten af det refleksive menneske, det vil sige dette at udvikle en eftertænksomhed over eget liv, egen identitet, valg af uddannelse efter egne præferencer - med en skelen til status og konsensus om de prestigiøse uddannelser - og finde egne ståsteder. Det sidste er næppe nyt, men i virkeligheden har moderniteten, og dermed den kulturelle frisættelse, sammen med udviklingen af velfærdsstaten, den kapitalistiske produktionsmåde og lønmodtagerkultur svækket den positive generationsreproduktion, især i forhold til familien og til at fastholde gamle firmaer og skabe nye foretagender og dermed levedygtige husholdninger.

\section{AFRUNDING}

For at forstå resiliens som noget mere end det, der bestemmes individuelt, påkalder jeg et fornyet fokus på, at robusthed også frembringes via en solid social reproduktion, om end denne kan være negativ, og muligheden for at skabe sig en tilværelse 
ud fra et levedygtigt hushold, slægt, dannelse, livsformer og lokale fællesskaber, med opmærksomhed på betydningen af langsigtede strategier og den selvstændige livsform.

Problemet er imidlertid, at medborgere i stigende grad bliver afhængige af andres virksomheder, offentlige institutioner (fx uddannelse) eller systemer i staten. En undtagelse er meget velstående og ressourcestærke familier og husholdninger (oikos) med langsigtede reproduktionsstrategier, som gennem mange generationer har formået at socialisere og positionere sine børn og dermed reproducere sociale positioner i samfundet. Studier viser dog, at det er muligt at lære fra disse typer af strategier og familieformer.

Når samfundet bliver mere uddannelseskrævende, mere institutionaliseret og mere komplekst med nye former for teknologi, forudsætter det i virkeligheden familier og individer båret af levedygtige husholdninger over mange generationer. Samfundsudviklingen er således et tveægget sværd, som derfor navnlig giver muligheder for privilegerede familier, især de som har overskud og kan klare mosten i de store byer med krav om meget uddannelse, kundskaber, fleksibilitet, kreativ produktion og excellence i fremmedsprog. For at alle kan få modstandskraft (resiliens), da den er ulige fordelt, er det oplagt, at alle får gavn og viden om de faktorer, der spiller ind på transmissionsprocesser i familien, og helt grundlæggende vil familier, husholdninger og slægter ikke kunne overleve uden at jorden, atmosfæren og naturen (den naturlige kapital) er intakt. Artiklen søger således at genkalde det livgivende og levedygtige hushold (oikos), den kapable og robuste familie, med understøttende værdier, der er i stand til at tage vare på sig selv og de kommende generationer, såvel socialt, arbejdsmæssigt, mentalt som økologisk.

\section{LITTERATUR}

Albertini, M., \& Kohli, M. (2013). The generational contract in the family: An analysis of transfer regimes in Europe. European Sociological Review, 29(4), 828-840.

Almlund, M., Duckworth, A., Heckman, J., \& Kautz, T. (2011). Personality psychology and economics, In E. Hanushek, S. Machin, \& L. Woessman (red.), Handbook of the economics of education (s. 1-181). Amsterdam: Elsevier.

Andresen, J., \& Højrup, T. (2008). The tragedy of enclosure. The battle for maritime resources and life-modes in Europe. Ethnologia Europaea, 38(1), 29-30. 
Atkinson, A. B., \& Søgaard, J. E. (2013). The long-run history of income inequality in Denmark: Top incomes from 1870 to 2010, EPRU Working Paper 2013-01.

Becker, S. O., \& Woessmann, L. (2009). Was Weber wrong? A human capital theory of protestant economic history. The Quarterly Journal of Economics, 124(2), 531-596.

Beyeler, M., Christoffersen, H., Eichenberger, R., Nannestad, P., \& Paldam, M. (2013). The good Society. A Comparative study of Denmark and Switzerland. Berlin: Springer Verlag.

Björklund, A., Roine, J., \& Waldenström, D. (2012). Intergenerational top income mobility in Sweden: Capitalistic dynasties in the land of equal opportunity? Journal of Public Economics, 96 (5-6), 474-484.

Boltanski, L., \& Thévenot, L. (2006 [1991]). On justification. Economies of worth. New Jersey: Princeton University Press.

Bonke, J., \& Munk, M. D. (2002). Fordeling af velford i Danmark. Resultater og perspektiver fra Socialforskningsinstituttets forskning om velfordsfordeling. København: SFI-rapport 02:27.

Bonke, J., Hussain, M. A., \& Munk, M. D. (2015). Money marries money - Intergenerational top household income mobility in Denmark, 9. november. Manuskript.

Boserup, S. H., Kopczuk, W., \& Thustrup Kreiner, C. (2014). Stability and persistence of intergenerational wealth formation: Evidence from Danish wealth records of three generations, 8. oktober. Manuskript.

Bourdieu, P. (1977). Outline of a theory of practice. Cambridge: Cambridge University Press.

Bourdieu, P. (1996 [1989]). The state nobility. Cambridge: Polity Press.

Bourdieu, P. (2005 [1972]). Udkast til en praksisteori. København: Hans Reitzels Forlag.

Bourdieu, P. (2014 [2012]). On the state. Cambridge: Polity Press.

Christoffersen, M. (2004). Familiens udvikling i det 20 århundrede. København: SFI rapport 04:07.

Cherlin, A. J. (2012). Goode's world revolution and family patterns: A reconsideration at fifty years. Population and Development Review, 38(4), 577-607.

Chetty, R., Hendren, N., Kline, P., \& Saez, E. (2014). Where is the land of opportunity? The geography of intergenerational mobility in the United States. Quarterly Journal of Economics, 129(4), 1553-1623.

Clark, G. (2014). The son also rises: Surnames and the history of social mobility. New Jersey: Princeton University Press.

Cox, C. A. (1998). Household interests. Property, marriage strategies, and family dynamics in ancient Athens. New Jersey: Princeton University Press.

Dahl, M. S., \& Sorensen, O. (2012). Home sweet home: Entrepreneurs' location choices and the performance of their ventures. Management Science, 58(6), 1059-1071. 
Dahl, K. M. (2014). Frihed, lighed og feellesskab i teenagefamilien. (Ph.d.-afhandling). København: Københavns Universitet.

Damgaard, E. (2002). Salling against the wind. Ethnologica Scandinavia, 32, 78-99.

Danmarks Statistik (2014a). Vielser og skilsmisser - skilsmisseprocent 2012. Nyt, Nr. 139, 18. marts 2013, rettet 7. marts 2014. København: Danmarks Statistik.

Danmarks Statistik (2014b). Generel firmastatistik 2012. Nyt, Nr. 376, 14. juli 2014. København: Danmarks Statistik.

Danmarks Statistik (2015). Befolkningens udvikling 2014. København: Danmarks Statistik.

Davies, J. K. (1992). Society and economy, i D.M. Lewis, J. Boardman, J.K. Davies, \& M. Ostwald, The Cambridge ancient history volume V: The fifth century B.C (s. 287-305). Cambridge: Cambridge University Press.

Esping-Andersen, G. (1990). The three world of welfare capitalism. Cambridge: Polity Press.

Esping-Andersen, G. (1999). Social foundations of postindustrial economies. Oxford: Oxford University Press.

Farkas, G. (2003). Cognitive skills and noncognitive traits and behaviors in stratification processes. Annual Review of Sociology, 29, 541-562.

Foxhall, L. (1989). Household, gender and property in classical Athens. The Classical Quarterly, 39(1), 22-44.

Friedman, S. (2014). The price of the ticket: rethinking the experience of social mobility. Sociology, $48(2), 352-368$.

Goode, W.J. (1970, [1963]). World Revolution and Family Patterns. New York: Free Press.

Harding, D. \& Munk, M. D. (2016). Why is intergenerational income mobility decreasing in a country with high social equality? Papir præsentation i sessionen Stratification \& Inequality, Annual Meeting of the American Sociological Association 2016.

Heckman, J. J. (2008). Schools, skills, and synapses. Economic Inquiry, 46(3), 289-324.

Højrup, T. (1995). Omkring livsformsanalysens udvikling. København: Museum Tusculanums Forlag.

Højrup, T. (2002). Den aristoteliske problematik i europæisk kulturteori, i T. Højrup, Dannelsens dialektik (s. 63-28). Københavnt: Museum Tusculanums Forlag.

Højrup, T. (2006). Gennem negation og konstruktion, i A. Jespersen, M. R. Melchior \& M. Sandberg, Verden over (s. 221-259). København: Museum Tusculanums Forlag.

Høst, J. (2015). Market-Based Fisheries Management: Private fish and captains of finance. Cham: Springer.

Jespersen, A. \& Sandberg, M. (2006). Hvad er et udgangspunkt? i A. Jespersen, M. R. Melchior, \& 
M. Sandberg, Verden over (s. 261-310). København: Museum Tusculanums Forlag.

Lacey, W. K. (1968). The family in classical Greece. London: Thames and Hudson.

Lenski, G. (1966). Power and privilege. New York: McGraw-Hill Book Company.

MacDowell, D. M. (1989). The oikos in Athenian law. The Classical Quarterly, 39(1), 10-21.

Mare, R. D. (2011). A multigenerational view of inequality. Demography, 48, 1-23.

Mare, R. D. (2014). Multigenerational aspects of social stratification: Issues for further research. Research in Social Stratification and Mobility, 35, 121-128.

Meikle, S. (1996). Aristotle on business. The Classical Quarterly, 46(1), 138-151.

Morgan, D. H. J. (1975). Social theory and the family. London: Routledge \& Kegan Paul.

Mulder, M. B., Bowles, S., Hertz, T., Bell, A., Beise, J., Clark, G.,...Wiessner, P. (2009). Intergenerational wealth transmission and the dynamics of inequality in small-scale societies. Science, 326(5953), 682-688.

Munk, M. D. (1990). En teori om praksis. Analysen tager afset $i$ Th. Højrups opfattelse af dialektik og kritik af P. Bourdieus praktikteori. (Kandidatspeciale). København: Københavns Universitet.

Munk, M. D. (2008). Køn, social mobilitet og social reproduktion - maskulin dominans og kvindernes indtog i uddannelsessystemet. Dansk Poedagogisk Tidsskrift, 56(2), 26-35.

Munk, M. D. (2013). Completion of upper secondary education: what mechanisms are at stake? Comparative Social Research, 30, 255-291.

Munk, M. D. (2014a). Social ulighed og uddannelse, i H. Dorf \& J. Rasmussen (red.), Grundbog $i$ peedagogisk sociologi? (s. 187-219). København: Hans Reitzels Forlag.

Munk, M. D. (2014b). Sådan forbliver samfundstoppen rig og magtfuld, Politologisk Årbog 2014, 87-91. København: Hans Reitzels Forlag.

Munk, M. D. (2015). Mekanismer, som påvirker den sociale mobilitet på videregående uddannelser, i C. M. P. Nielsen, M. D. Munk, M.T. Jensen, K. Karmsteen, \& A-M. K. Jørgensen, Mønsterbryderindsatser på de videregående uddannelser (s. 31-42). København: SFI rapport 15:21.

Munk, M. D., Foged, M., \& Mulvad, A. (2011). Familiers kosmopolitiske uddannelsesstrategier - Et spørgsmål om migration og investering i distinktiv kapital. Dansk Sociologi, 22(3), 31-58.

Munk, M. D., Bohn, L., \& Baklanov, N. (2015). Grundforløbspakker og frafald på danske erhvervsskoler. Aalborg: Aalborg Universitetsforlag.

Munk, M. D., Bonke, J., \& Hussain M. A. (2016). Intergenerational top income persistence: Denmark half the size of Sweden. Economics Letters, 140, 31-33.

Olsson, L., Jerneck, A., Thoren, H., Persson, J., \& O’Byrne, D. (2015). Why resilience is unappealing to social science: theoretical and empirical investigations of the scientific use of resilience. Science Advances, 1, e1400217, 1-11. 
Pedersen, O. K. (2011). Konkurrencestaten. København: Hans Reitzels Forlag.

Pedersen, O. K. (2014). Markedsstaten. København: Hans Reitzels Forlag.

Piketty, T. (2014). Capital in the twenty-first century. Cambridge, Ma.: The Belknap Press of Harvard University Press

Polanyi, K. (2001 [1944]). The great transformation. The political and economic origins of our time. Boston: Beacon Press.

Rahbek Christensen, L. (1987). Hver vore veje - livsformer, familietyper og kvindeliv. København: Museum Tusculanum.

Sabiers, S. E. (2014). Uddannelse i de sociale klasser i 2012. Analysenotat. København: AE-rådet.

Schaltegger, C. A., \& Torgler, B. (2010). Work ethic, protestantism, and human capital. Economics Letters, 107(2), 99-101.

Sorensen, J. B., \& Sharkey, A. (2014). Entrepreneurship as a mobility process. American Sociological Review, 79(2), 328-349.

Tönnies, F. (1957 [1887]). Community and Society. East Lansing: The Michigan State University Press

Zellweger, T. M., Nason, R. S., \& Nordqvist M. (2012). From longevity of firms to transgenerational entrepreneurship of families: introducing family entrepreneurial orientation. Family Business Review, 25(2), 136-155.

Weber, M. (1978 [1922]). Economy and society. Berkeley: University of California Press.

Weber, M. (1995 [1904-1905]). Den protestantiske etik og kapitalismens ånd. København: Nansensgades antikvariat. 
